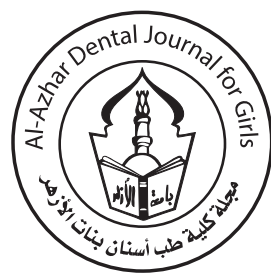

\title{
Effect of Repeated Firings on the Color Change and Surface Roughness of Two All-ceramic Systems
}

\author{
Sherehan A. Mohamed ${ }^{1 *}$, Atef F. Ahmed ${ }^{2}$,Walaa O. Mekkawi ${ }^{3}$
}

Codex : 43/20.07

azhardentj@azhar.edu.eg

http://adjg.journals.ekb.eg

DOI: $10.21608 /$ adjg.2020.14214.1185

Restorative Dentistry

(Removable Prosthodontics, Fixed

Prosthodontics, Endodontics, Dental Biomaterials, Operative Dentistry)

\section{KEYWORDS}

Repeated Firings, Color,

Roughness, Ceramic.

\begin{abstract}
Purpose: This study aimed to evaluate the effect of repeated firings on the color change and surface roughness of two all-ceramic systems. Materials and Methods: Forty disc shaped ceramic specimens ( $10 \mathrm{~mm} \times 1 \mathrm{~mm}$ ) were fabricated from two commercially available all-ceramic system (IPS E.max press, Ivoclar-Vivadent, Schaan, Liechtenstien, Germany and zirconia Nacera Pearl, DOCERAM Medical Ceramics, Germany) ( $\mathrm{N}=20$ ). Color measurement of the specimens was made using Reflective spectrophotometer and surface roughness (Ra) was measured using USB digital profile guage, (Elcometer 224/2, Elcometer Instruments, Great Britain) after 1, 3, 5 and 7 repeated firing. Results: The mean color change $(\Delta \mathrm{E})$ was clinically acceptable for both types of ceramics. As regards the effect of ceramic material on $(\Delta \mathrm{E})$, e.max showed statistically significantly higher mean color change $(\Delta \mathrm{E})$ than Zirconia. As regards the effect of repeated firings on $(\Delta E), 7$ repeated firings showed statistically significantly higher mean $(\Delta \mathrm{E})$ than 5 repeated firings which in turn showed statistically significantly higher mean $(\Delta E)$ than 3 repeated firings. Surface roughness measurements showed that there were significant difference between E.max and zirconia and that zirconia showed higher mean (Ra) than e.max. Also the results of the current study showed that there were a significant difference between mean $(\mathrm{Ra})$ and numbers of firing as roughness decrease with increasing the number of firing. Conclusions: Repeated firings negatively affecting the color change and surface roughness and should be minimized as possible.
\end{abstract}

\section{INTRODUCTION}

For producing more natural looking restorations dental ceramics have been used for a long term because of their superior esthetic and bio-mechanical properties ${ }^{(1)}$. Advanced ceramic systems and fabricating techniques were introduced as a result of developments in dental

1. Dentist at Ministry of Health, Egypt

2. Professor and Head of Crowns and Bridges Department, Faculty of Dental Medicine for Girls, Al-Azhar University, Cairo, Egypt.

3. Lecturer of Crowns and Bridges, Faculty of Dental Medicine for Girls, Al-Azhar University , Cairo, Egypt.

* Corresponding author email: sherry.sa22@gmail.com 
industry. Various fabricating methods as lost wax, slip cast and CAD/CAM are used for fabrication of most frequently used all-ceramic restorations such as lithium disilicate, aluminum oxide and zirconium oxide ceramics ${ }^{(2,3)}$.

According to the laboratory procedure allceramic systems can be classified to (pressable, sintering, slip casting or milling) and according to components all-ceramic systems can be classified to (feldspar, glass ceramic, core reinforced) $)^{(4,5)}$. Pressable glass ceramics are frequently used due to easiness of fabrication, occlusal accuracy, translucency, enhanced marginal integrity, excellent mechanical properties, reduced porosity and net shaped forming by pressing $g^{(6,7)}$.

As metal free restorations Lithium disilicate ceramics gain their celebrity. They can be used as full-anatomical restorations, laminate veneers, inlays, onlays or as core material covered by veneering ceramics ${ }^{(8)}$.

Zirconia ceramics, can be used as core materials in all-ceramic restorations, implant materials, implant superstructures and orthodontic brackets due to their superior strength and fracture toughness ${ }^{(9)}$.

For better mechanical properties lithium disilicate ceramics are material of choice in comparison with leucite based ceramics and for superior esthetic outcome lithium disilicate ceramics are much better than zirconia ceramics ${ }^{(8)}$.

It is necessary to duplicate natural teeth color. The main factors which affects reproduction of the ceramic color are related to components of substructures, type of ceramic, manufacturing procedures, ceramic thickness, and processing variables in ceramic firing such as number of firings and firings temperature ${ }^{(10,11)}$. Dental ceramics are subjected to firings during manufacture procedure .Sometimes repeated firings are necessary for esthetic causes, as color mismatch and occlusal correction $^{(8)}$. The statement "Repeated firings" may be defined as the supplementary firing after production of the restoration due to esthetic and occlusal correction. In another study it was revealed that there was a little variations in ceramics color after repeated firings ${ }^{(12)}$. A pervious study reported that detectable color changes can take a place after three to six repeated firings on layering ceramic ${ }^{(13)}$.

Color evaluation is a complex psycho-physiological process subjected to many variables ${ }^{(14,15)}$. By the use of CIEL*a*b* color system colorimetric measurements can provide exact color values. The commission International de I'Eclairage (International Commission on Illumination) system was developed in $1978^{(15,16)}$. CIEL*a*b* describes color in 3 dimensions:( $\mathrm{L}^{*}, \mathrm{a}^{*}$ and $\left.\mathrm{b}^{*}\right), \mathrm{L}^{*}$ represents lightness $(0-100), a^{*}$ represents color variation axis red/ green and $b^{*}$ represent color variation axis yellow/ blue. The color difference or change is acknowledged by $\Delta \mathrm{E}^{(17)}$. The perception level of $\Delta \mathrm{E}$ changes is from 1 to 3.7 in several studies but most of studies revealed that color change $(\Delta \mathrm{E})$ under 1 unit cannot be detectable by eyes ${ }^{(18-20)}$.

Surfaces of restorations have to be smooth and polished, or else rough surfaces may cause reduction in flexural strength, increase in surface staining on teeth because of increased abrasion in surface of opposing teeth and accumulation of plaque and calculus ${ }^{(21-24)}$. Accordingly, increased possibility to infection in oral soft tissue and dental caries and decrease in the esthetic outcome of the restoration may occur ${ }^{(25-27)}$. Smoothness of ceramic restorations can be accomplished by glaze process which includes subjecting dental ceramic to temperature that is lower than fusing temperature of the ceramic ${ }^{(28,29)}$.

Therefore, this study was designed to evaluate the effect of repeated firings on the color change and surface roughness of two all ceramic systems. The hypothesis of this study was that both color and surface roughness of lithium disilicate and zirconia would be affected by repeated firings. 


\section{MATERIALS AND METHODS}

IPS e.max press, Ivoclar-vivadent, schaan, Liechtenstien, Germany and Zirconia Nacera Pearl, DOCERAM Medical Ceramics, Germany were used in this study. Size of specimens for this study was similar to the specimen size used in previous color evaluation studies ${ }^{(30-32)}$.

\section{Preparations of IPS e-max press specimens}

Lithium disilicate ceramic specimens were made-up following the manufacturer's instructions using lost wax technique. Totally 20 disc shaped standardized wax patterns were produced using CAD/CAM technology for standardization. First a file with the desired dimensions $(1 \mathrm{~mm}$ in thickness and $10 \mathrm{~mm}$ in diameter) was created then this file was opened with a software program (MILLBOX DG SHAPE V3.7.3) and activated to start milling wax pattern specimens. The CAD/CAM waxpatterns were fabricated using a milling machine (Roland DWX-510 Japan).The specimens were first invested and after that burned out at $850^{\circ} \mathrm{C}$ for 1 hour. IPS e-max press ingots were used to produce the ceramic specimens by heat-press technique at $700^{\circ} \mathrm{C}$ in press furnace (EP 3010, Ivoclarvivadent,schaan,liechtenstien). The specimens were then divested $2 \mathrm{~mm}$ away from the specimens. The specimens were checked for the desired thickness using a stainless steel caliper (Pirmadent, Germany Stainless) by measuring different points (one point centrally and four equidistant points at the periphery). All specimens were glazed following manufacturer's instructions.

\section{Preparation of zirconia specimens}

Zirconia ceramic specimens were made-up according to manufacturer's instructions using CAD/CAM technique. Totally 20 disc specimen $(1 \mathrm{~mm}$ in thickness and $10 \mathrm{~mm}$ in diameter ) were designed using a software (MILLBOX DG SHAPE V3.7.3), dimensions of specimens were adjusted taking into account the expected amount of shrinkage during sintering which is specified by the manufacturer.After milling all specimens were sintered in sintering furnace (Tabeo-1/s/ zircon-100,Germany), and glazed following the manufacturer's instructions. The specimens were checked for the desired thickness using a caliper (Pirmadent , Germany Stainless) by measuring different points (one point centrally and four equidistant points at the periphery).

Twenty specimens of each ceramic systems were prepared and then subjected to the repeated firings $\left(3^{\text {rd }}, 5^{\text {th }}\right.$ and $\left.7^{\text {th }}\right)$. The control group was the specimens that were glazed first time. The glaze firing cycle was repeated three, five and seven times.

Table (1): The repeated glaze firing cycles for e.max

\begin{tabular}{|c|c|c|c|c|c|c|}
\hline $\begin{array}{c}\text { Stand-by temp. } \\
\left({ }^{\circ} \mathbf{C} /{ }^{\circ} \mathbf{F}\right)\end{array}$ & $\begin{array}{c}\text { Closing temp. } \\
(\mathbf{m i n})\end{array}$ & $\begin{array}{c}\text { Temperature } \\
\text { increase rate } \\
\left({ }^{\circ} \mathbf{C} /{ }^{\circ} \mathbf{F} / \mathbf{m i n} \text { ) }\right.\end{array}$ & $\begin{array}{c}\text { Firing temp. } \\
{ }^{\circ} \mathbf{C} /{ }^{\circ} \mathbf{F}\end{array}$ & $\begin{array}{c}\text { Holding time } \\
(\mathbf{m i n} .)\end{array}$ & $\begin{array}{c}\text { Vacuum-on } \\
\text { temp. }\left({ }^{\circ} \mathbf{C} /{ }^{\circ} \mathbf{F}\right)\end{array}$ & $\begin{array}{c}\text { Vacuum-off temp } \\
\left({ }^{\circ} \mathbf{C} /{ }^{\circ} \mathbf{F}\right)\end{array}$ \\
\hline $403 / 757$ & $6: 00$ & $60 / 108$ & $770 / 1418$ & $1: 00-2: 00$ & $450 / 842$ & $769 / 1416$ \\
\hline
\end{tabular}

Table (2) : The repeated glaze firing cycle for Zirconia

\begin{tabular}{|c|c|c|c|c|}
\hline Firing temperature $\left({ }^{\circ} \mathbf{C}\right)$ & Holding time (min) & Drying time (min) & Vacuum on $\left({ }^{\circ} \mathbf{C}\right)$ & Vacuum off $\left({ }^{\circ} \mathbf{C}\right)$ \\
\hline 820 & 2 & 2 & 400 & 800 \\
\hline
\end{tabular}

Color and surface roughness measurements were preformed and recorded for each specimen in control group and after the $3^{\text {rd }}, 5^{\text {th }}$ and $7^{\text {th }}$ repeated firings. 


\section{Color change measurements}

The color was calculated using reflective spectrophotometer. Size of the aperture was set to $4 \mathrm{~mm}$ and the specimens were exactly aligned with the device. White background was selected, 3 measurements were made at glazed surface of each disc, the average reading was calculated for each specimen, and measurements were made according to the CIELab color space relative to the CIE standard illuminant D65. Specimens' color change $(\Delta \mathrm{E})$ were evaluated via the following formula:

$$
\Delta \mathrm{E}_{\text {CIELAB }}=\left(\Delta \mathrm{L}^{* 2}+\Delta \mathrm{a}^{* 2}+\Delta \mathrm{b}^{* 2}\right) \frac{1 / 2}{2} \text { Where: } \mathrm{L}^{*}
$$
stand for brightness-darkness, $\mathrm{a}^{*}$ stand for rednessgreenness, $b^{*}$ stand for yellowness-blueness of the object.(Figure 1)

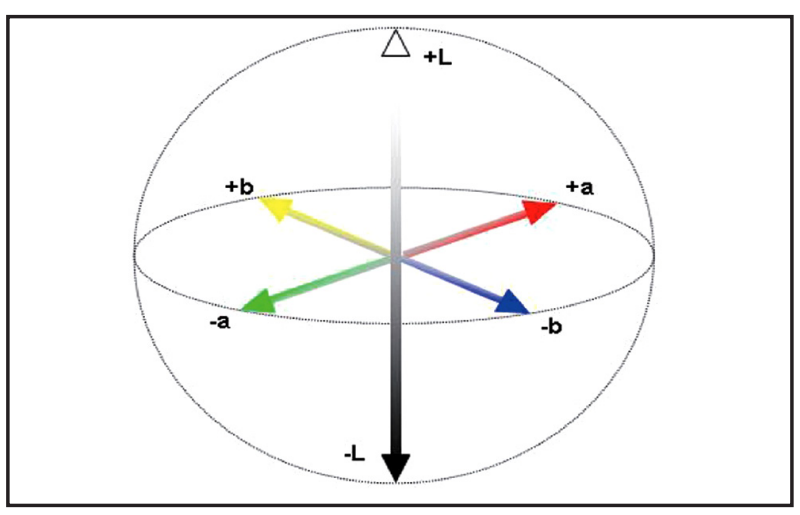

Figure (1): Diagram of CIE L*a*b* system.

\section{Surface roughness (Ra) measurements}

Surface roughness ( $\mathrm{Ra}$ ) was evaluated using USB digital surface profile gauge, (Elcometer 224/2, Elcometer Instruments, Great Britain) and data were recorded using computer software of roughness tester supplier (Elcomaster 2, Elcometer Instruments). For each reading made, the mean roughness value (Ra,um) was represented by the arithmetic mean between the peaks and valleys registered, after the needle of the profilometer had scanned a stretch of $2 \mathrm{~mm}$ in length, with a cutoff of $0.25 \mathrm{~mm}$ to maximize the filtering and the undulation on the surface. Each surface was read three times, from three different points starting from center of the specimen. The mean values of the three readings yielded the mean value of the roughness of each specimen.

\section{Statistical analysis:}

The mean and standard deviation values were recorded for each group in each test. Data were investigated for normality using KolmogorovSmirnov and Shapiro-Wilk tests, data showed parametric (normal) distribution.

One-way ANOVA followed by Tukey post hoc test was used to compare between more than two groups in non-related samples. Independent sample t-test was used to compare between two groups in non-related samples.

The significance level was set at $\mathrm{P} \leq 0.05$. Statistical analysis was performed with IBM ${ }^{\circledR}$ SPSS ${ }$ Statistics Version 20 for Windows.

\section{RESULTS}

The statistical analysis of the results showed that:

I) Color change measurements $(\boldsymbol{\Delta E})$ : (Table 3)

- There was statistically significant difference between (Lithium disilicate) and (Zirconia) in color change $(p<0.001)$.

- As regards the effect of ceramic material on color change IPS e.max has higher $(\Delta \mathrm{E})$ value than zirconia.

- As regards the effect of number of firings on $(\Delta \mathrm{E}), 7$ repeated firings demonstrated statistically significantly higher mean $(\Delta \mathrm{E})$ than 5 repeated firings which in turn demonstrated statistically significantly higher mean $(\Delta \mathrm{E})$ than 3 repeated firings. 
Table (3): The mean and (SD) values of $\Delta \mathrm{E}$ of different groups.

\begin{tabular}{|c|c|c|c|c|c|c|c|c|c|}
\hline \multirow{3}{*}{ Variables } & \multicolumn{9}{|c|}{$\Delta \mathbf{E}$} \\
\hline & \multicolumn{2}{|c|}{ Initial firing } & \multicolumn{2}{|c|}{ After 3 firing cycles } & \multicolumn{2}{|c|}{ After 5 firing cycles } & \multicolumn{2}{|c|}{ After 7 firing cycles } & \multirow{2}{*}{ P-value } \\
\hline & Mean & SD & Mean & SD & Mean & SD & Mean & SD & \\
\hline Lithium disilicate & 3.67 & 0.44 & 5.13 & 0.60 & 6.50 & 0.65 & 7.96 & 0.58 & $<0.001^{*}$ \\
\hline Zirconia & 2.10 & 0.49 & 3.12 & 0.78 & 4.48 & 0.93 & 5.37 & 0.90 & $<0.001^{*}$ \\
\hline P-value & \multicolumn{2}{|c|}{$<0.001^{*}$} & \multicolumn{2}{|c|}{$0.001 *$} & \multicolumn{2}{|c|}{$0.001 *$} & \multicolumn{2}{|c|}{$<0.001^{*}$} & \\
\hline
\end{tabular}

P-value $<0.05$ : significant (*);non-significant $>0.05$ (ns)

\section{II) Color change measurements ( $\Delta \mathbf{L})$ : (Table 4$)$}

- There was statistically significant difference between (Lithium disilicate) and (Zirconia) in $(\Delta \mathrm{L})$ value $(p<0.001)$.

- As regards the effect of ceramic material on $(\Delta \mathrm{L})$ IPS e.max has higher $(\Delta \mathrm{L})$ value than zirconia.

- Regards the effect of number of firings on $(\Delta \mathrm{L})$, there was a statistically significant decrease in $(\Delta \mathrm{L})$ as the number of firing increase.

Table (4): The mean and $S D$ values of $\Delta L$ of different groups.

\begin{tabular}{|c|c|c|c|c|c|c|c|c|c|}
\hline \multirow{3}{*}{ Variables } & \multicolumn{9}{|c|}{$\Delta \mathbf{L}$} \\
\hline & \multicolumn{2}{|c|}{ Initial firing } & \multicolumn{2}{|c|}{ After 3 firing cycles } & \multicolumn{2}{|c|}{ After 5 firing cycles } & \multicolumn{2}{|c|}{ After 7 firing cycles } & \multirow{2}{*}{ P-value } \\
\hline & Mean & SD & Mean & SD & Mean & SD & Mean & SD & \\
\hline Lithium disilicate & 5.46 & 0.39 & 4.50 & 0.65 & 3.13 & 0.60 & 2.67 & 0.44 & $<0.001 *$ \\
\hline Zirconia & 3.04 & 0.67 & 2.48 & 0.93 & 1.35 & 0.47 & 1.02 & 0.14 & $<0.001 *$ \\
\hline P-value & \multicolumn{2}{|c|}{$<0.001 *$} & \multicolumn{2}{|c|}{$<0.001^{*}$} & \multicolumn{2}{|c|}{$<0.001^{*}$} & \multicolumn{2}{|c|}{$<0.001^{*}$} & \\
\hline
\end{tabular}

P-value $<0.05$ : significant $(*)$;non-significant $>0.05$ (ns)

\section{III) Color change measurements ( $\Delta \mathbf{a})$ : (Table 5)}

- Zirconia showed statistically significantly higher $(\Delta \mathrm{a})$ value than e.max.

○ There was a statistically significant increase in $(\Delta \mathrm{a})$ after 3,5 and 7 repeated firings .

- Highest mean of $(\Delta \mathrm{a})$ value was obtained with 7 repeated firings while lowest $(\Delta \mathrm{a})$ value was obtained with the control group.

Table (5): The mean and $S D$ values of $\Delta a$ of different groups.

\begin{tabular}{|c|c|c|c|c|c|c|c|c|c|}
\hline \multirow{3}{*}{ Variables } & \multicolumn{9}{|c|}{$\Delta \mathbf{a}$} \\
\hline & \multicolumn{2}{|c|}{ Initial firing } & \multicolumn{2}{|c|}{ After 3 firing cycles } & \multicolumn{2}{|c|}{ After 5 firing cycles } & \multicolumn{2}{|c|}{ After 7 firing cycles } & \multirow{2}{*}{ P-value } \\
\hline & Mean & SD & Mean & SD & Mean & SD & Mean & SD & \\
\hline Lithium disilicate & 0.96 & 0.11 & 1.46 & 0.30 & 2.17 & 0.59 & 2.80 & 0.65 & $0.002 *$ \\
\hline Zirconia & 1.93 & 0.14 & 2.68 & 0.42 & 3.32 & 0.46 & 4.16 & 0.57 & $<0.001 *$ \\
\hline P-value & \multicolumn{2}{|c|}{$<0.001^{*}$} & \multicolumn{2}{|c|}{$<0.001 *$} & \multicolumn{2}{|c|}{$0.004 *$} & \multicolumn{2}{|c|}{$0.003 *$} & \\
\hline
\end{tabular}

$P$-value $<0.05$ : significant $(*)$; non-significant $>0.05$ (ns) 
IV) Color change measurements $(\Delta \mathbf{b})$ : (Table 6)

- There was statistically significant difference in $(\Delta \mathrm{b})$ between the two ceramic materials.

$\circ$ There was a statistically significant increase in $(\Delta b)$ after 3,5 and 7 repeated firings .

- Highest mean of $(\Delta b)$ value was obtained with 7 repeated firings while lowest $(\Delta b)$ value was obtained with the control group.

Table (6): The mean and $S D$ values of $\Delta b$ of different groups.

\begin{tabular}{|c|c|c|c|c|c|c|c|c|c|}
\hline \multirow{2}{*}{ Variables } & \multicolumn{7}{|c|}{$\Delta \mathbf{b}$} \\
\cline { 2 - 11 } & \multicolumn{2}{|c|}{ Initial firing } & \multicolumn{2}{|c|}{ After 3 firing cycles } & \multicolumn{2}{c|}{ After 5 firing cycles } & \multicolumn{2}{c|}{ After 7 firing cycles } & \multirow{2}{*}{ P-value } \\
\cline { 2 - 11 } & Mean & SD & Mean & SD & Mean & SD & Mean & SD & \\
\hline Lithium disilicate & 0.70 & 0.18 & 1.16 & 0.30 & 1.87 & 0.59 & 2.33 & 0.48 & $<0.001 *$ \\
\hline Zirconia & 1.09 & 0.09 & 1.69 & 0.27 & 2.48 & 0.78 & 2.91 & 0.42 & $<0.001^{*}$ \\
\hline P-value & \multicolumn{2}{|c|}{$0.001^{*}$} & \multicolumn{2}{|c|}{$0.009 *$} & $0.153 \mathrm{~ns}$ & & $0.051 \mathrm{~ns}$ & \\
\hline
\end{tabular}

P-value $<0.05:$ significant (*);non-significant $>0.05$ (ns)

\section{V) Surface roughness (Ra): (Table 7)}

- As regards the effect of ceramic material on surface roughness, e.max demonstrated statistically significantly lower mean $(\mathrm{Ra})$ than Zirconia.

- As regards the effect of repeated firings on surfaces roughness, initial firing demonstrated the statistically significantly highest mean (Ra). This was followed by 3 repeated firings. 5 repeated firings and 7 repeated firing which demonstrated the statistically significantly lowest mean $(\mathrm{Ra})$.

Table (7): The mean and SD values of Roughness ( $R a)$ of different groups.

\begin{tabular}{|c|c|c|c|c|c|c|c|c|c|}
\hline \multirow{2}{*}{ Variables } & \multicolumn{7}{|c|}{ Roughness (Ra) } \\
\cline { 2 - 12 } & \multicolumn{2}{|c|}{ Initial firing } & \multicolumn{2}{c|}{ After 3 firing cycles } & \multicolumn{2}{c|}{ After 5 firing cycles } & \multicolumn{2}{c|}{ After 7 firing cycles } & \multirow{2}{*}{ p-value } \\
\cline { 2 - 12 } & Mean & SD & Mean & SD & Mean & SD & Mean & SD & \\
\hline Lithium disilicate & 0.2795 & 0.0007 & 0.2592 & 0.0084 & 0.2475 & 0.0106 & 0.2340 & 0.0049 & $0.004^{*}$ \\
\hline Zirconia & 0.3082 & 0.0062 & 0.2887 & 0.0054 & 0.2699 & 0.0067 & 0.2592 & 0.0067 & $0.007^{*}$ \\
\hline P-value & \multicolumn{2}{|c|}{$0.001^{*}$} & \multicolumn{2}{|c|}{$0.007 *$} & & $0.036^{*}$ & & $0.006^{*}$ & \\
\hline
\end{tabular}

P-value <0.05: significant (*);non-significant $>0.05$ (ns) 


\section{DISCUSSION}

All-ceramic restorations allow superior light transmission within the restoration, which enhances the color and translucency of the final restorations ${ }^{(33)}$. For better mechanical properties lithium disilicate ceramics are material of choice in comparison with leucite based ceramics and for superior esthetic outcome lithium disilicate ceramics are much better than zirconia ceramics ${ }^{(8)}$.

Fabricating all-ceramic fixed partial dentures without any limitation regarding the size of the restoration became more applicable after the existence of zirconium dioxide ${ }^{(34)}$. Yttria-stabilized tetragonal Zirconia (Y-tzp) is frequently used as dental restorations because of its excellent mechanical properties and bio-compatibility ${ }^{(35)}$. Zircoina is now used as a core material in all ceramic restoration and orthodontic brackets ${ }^{(36,37)}$. The exceptional properties of Zirconia as strength, transformation toughening, white color, chemical and structural stability made Zirconia the core material of choice ${ }^{(38)}$.

Current color matching instrument are able to reliably quantify color of both tooth and dental ceramic by measuring color and expressing it in terms of three coordinate values $\left(\mathrm{L}^{*}, \mathrm{a}^{*}\right.$ and $\mathrm{b}^{*}$ ) which locate the object's color in the CIE-lab color space $^{(39,40)}$.

Instrumental measurement devices, like spectrophotometers and colorimeters are capable of detecting and quantifying slight color differences as their limitation of detection during in vitro quantification of mono chromatic specimens is considered to be $1 \Delta \mathrm{E}$ units ${ }^{(20)}$. Spectrophotometers are the preferred instrument for measurement of color as they are quite stable over time, accurate and can evaluate metamerism in contrast to colorimeters that cannot quantify metamerism and have poor repeatability and reproducibility due to aging of the filters $^{(41)}$.
It is believed that surface roughness may affect the esthetic by changing the texture of ceramic restoration so it affects color stability by increasing scattering of incident light ${ }^{(42)}$.

The profilometer has the ability to characterize and quantify surface roughness, step heights, critical dimensions and other topographical features with outstanding accuracy. Measurements are non destructive, quick and don't need specimen preparation.

Results of color parameter of this study showed that e.max has a higher mean $(\Delta \mathrm{E})$ than zirconia irrespective to number of firings, and the color change $(\Delta \mathrm{E})$ was clinically acceptable for both types of ceramic. This difference may be because of the difference in core crystal volume, refractive index and crystalline content between the two materials $^{(43)}$.

These results were consistent with the information provided by previous studies ${ }^{(14,44-47)}$. This phenomena can be explained as the $(\Delta \mathrm{E})$ of ceramic systems were affected by the ceramic composition, as the zirconia uses pure partially stabilized zirconia particles, while IPS e-max consists of lithium disilicate crystals to strengthen the matrix ${ }^{(14)}$, it was suggested that ceramic core composition is affected by repeated firings ${ }^{(44)}$.

Studying the effect of repeated firings on color change $(\Delta \mathrm{E}), 7$ repeated firings have a statistically significant higher mean $(\Delta \mathrm{E})$ value that was clinically detectable by all observers, than five repeated firings which in turn have higher mean $(\Delta \mathrm{E})$ than 3 repeated firings which show color change $(\Delta \mathrm{E})$ within the clinically acceptable limit; this may be related to color instability of metal oxides during repeated firings.

These results were in agreement with previous studies ${ }^{(14,44,45,48,49)}$. This could be explained due to instability of metal oxides after repeated firing temperatures, and changes of surface colorants and pigment breakdown after repeated firings ${ }^{(50,51)}$. 
Considering the mean $\mathrm{L}^{*}$ value which was statistically significant higher in e.max than zirconia and always decreased in ceramic materials used after repeated firings, while the mean $\mathrm{a}^{*}$ value was higher for zirconia than e.max and the mean $b^{*}$ value showed no statistically significant difference, this is attributable to the fact that the $\mathrm{L}^{*} \mathrm{a}^{*} \mathrm{~b}^{*}$ values of ceramic systems were affected by the ceramic compositions $^{(48)}$.

The results of the current study also showed that the mean $L^{*}$ value decreased with repeated firings while the mean $\mathrm{a}^{*}$ and $\mathrm{b}^{*}$ values increased which is consistent with previous study ${ }^{(48)}$.

The resulted color coordinates proved that the final discs specimens were darker, redder and more yellowish colors. That was in agreement with previous studies ${ }^{(14,52)}$ who studied the color stability of different type of dental ceramic and reported that the greater the number of firing, the darker and more reddish/yellowish the specimens, indicating smaller $\mathrm{L}^{*}$ and greater $\mathrm{a}^{*}$ and $\mathrm{b}^{*}$ coordinates.

Surface roughness measurements showed that there was a significant difference between zirconia and e.max and that zirconia showed a higher mean (Ra) than e.max which may be due to the presence of abrasive alumina and voids in the structure of the zirconia $^{(53)}$.

This was found to be in agreement with pervious study ${ }^{(54)}$ which may be due the presence of alumina crystals in addition to the glass powder, and such a granular and porous structure, may cause greater roughness.

Also the results of the current study showed that there was a significant difference between mean (Ra) and numbers of firing as roughness decrease with increasing the number of firing as a result of the melting and fusion of the surface of the porcelain that fill in small irregularities, thereby providing the restoration with a smoother surface ${ }^{(55)}$.

This result is in agreement with previous studies ${ }^{(56,57)}$ this phenomenon may be due to the effect of sintering time and temperature on decreasing of the porosity, as trapped gasses escape by diffusion through the matrix ${ }^{(57)}$ and that the glaze layer fills the microcracks and form a smooth layer.

\section{CONCLUSIONS}

Within the limitations of this in-vitro study the following conclusions were drawn:

1. E.max and Zirconia ceramic materials acted differently as regards color change $(\Delta \mathrm{E})$ and surface roughness $(\mathrm{Ra})$.

2. Color change $(\Delta \mathrm{E})$ and the roughness of ceramic surface were affected by the type of ceramic used as well as number of firings with the higher $(\Delta \mathrm{E})$ value and least roughness produced with e.max after 7 repeated firings

\section{REFERENCES}

1. Molin M, Karlsson S. A clinical evaluation of the Optec inlay system. Acta Odontol Scand. 1992;50:227-33.

2. Denry I, Holloway JA. Ceramics for dental applications: a review. Materials (Basel). 2010;3:351-68.

3. Deany IL. Recent advances in ceramics for dentistry. Crit Rev Oral Biol Med. 1996;7:134-43.

4. O'Brien WJ. Dental materials and their selection. 3rd ed. Chicago: Quintessence. 2002; 210-24.

5. Albakry M, Guazzato M, Swain MV. Biaxial flexural strength, elastic moduli, and x-ray diffraction characterization of three pressable all-ceramic materials. J Prosthet Dent. 2003; 89:374-80.

6. Cattell MJ, Clarke RL, Lynch EJ. The biaxial flexural strength and reliability of four dental ceramics - Part II. J Dent.1997; 25:409-14.

7. Gorman CM, McDevitt WE, Hill RG. Comparison of two heat-pressed all-ceramic dental materials. Dent Mater. 2000; 16:389-95.

8. Yilmaz K, Gonuldas F, Ozturk C. The effect of repeated firings on the color change of dental ceramics using different glazing methods. J Adv Prosthodont. 2014;6:427-33.

9. Ananth H, Kundapur V, Mohammed HS, Anand M, Amarnath GS, Mankar S. A review on biomaterials in dental implantology. Int J Biomed Sci. 2015;11:113-20. 
10. Shokry TE, Shen C, Elhosary MM, Elkhodary AM. Effect of core and veneer thicknesses on the color parameters of two all ceramic systems. J Prosthet Dent. 2006;95:124-9.

11. Hammad IA, Stein RS. A qualitative study for the bond and color of ceramo metals. Part II. J Prosthet Dent. 1991;65:169-79.

12. Barghi N, Goldberg J. Porcelain shade stability after repeated firing. J Prosthet Dent. 1997;37:173-5.

13. O’Brien WJ, Kay KS, Boenke KM, Groh CL. Sources of color variation on firing porcelain. Dent Mater. 1991;7:170-3.

14. Uludag B, Usumez A, Sahin V, Eser K, Ercoban E. The effect of ceramic thickness and number of firings on the color of ceramic systems: An in vitro study. J Prosthet Dent. 2007; 97:25-31.

15. Heydecke G, Zhang F, Razzoog ME. In vitro color stability of double-layer veneers after accelerated aging. J Prosthet Dent, 2001; 85:551-7.

16. Ertan AA, Sahin E. Colour stability of low fusing porcelains: an in vitro study. J Oral Rehabil.2005; 32:358-61.

17. Douglas RD, Steinhauer TJ, Wee AG. Intraoral determination of the tolerance of dentists for perceptibility and acceptability of shade mismatch. J Prosthet Dent. 2007; 97:200-8.

18. Ruyter IE, Nilner K, Moller B. Color stability of dental composite resin materials for crown and bridge veneers. Dent Mater.1987; 3:246-51.

19. Douglas RD, Brewer JD. Acceptability of shade differences in metal ceramic crowns. J Prosthet Dent. 1998; 79:254-60.

20. Seghi RR, Hewlett ER, Kim J. Visual and instrumental colorimetric assessments of small color differences on translucent dental porcelain. J Dent Res. 1989; 68:1760-4.

21. Bessing C, Wiktorsson A. Comparison of two different methods of polishing porcelain. Scand J Dent Res. 1983;91: 482-7.

22. Al-Hiyasat AS, Saunders WP, Sharkey SW, Smith GM, Gilmour WH. The abrasive effect of glazed, unglazed, and polished porcelain on the wear of human enamel, and the influence of carbonated soft drinks on the rate of wear. Int J Prosthodont .1997;10:269-82.

23. Sasahara RM, Ribeiro Fda C, Cesar PF, Yoshimura HN. Influence of the finishing technique on surface roughness of dental porcelains with different microstructures. Oper Dent 2006;31:577-83.
24. Clayton JA, Green E. Roughness of pontic materials and dental plaque. J Prosthet Dent .1970;23:407-11.

25. Kawai K, Urano M, Ebisu S. Effect of surface roughness of porcelain on adhesion of bacteria and their synthesizing glucans. J Prosthet Dent. 2000;83:664-7.

26. Martínez-Gomis J, Bizar J, Anglada JM, Samsó J, Peraire M. Comparative evaluation of four finishing systems on one ceramic surface. Int J Prosthodont. 2003;16:74-7.

27. Brewer JD, Garlapo DA, Chipps EA, Tedesco LA. Clinical discrimination between autoglazed and polished porcelain surfaces. J Prosthet Dent. 1990;64:631-4.

28. Cook PA, Griswold WH, Post AC. The effect of superficial colorant and glaze on the surface texture of vacuum-fired porcelain. J Prosthet Dent .1984;51:476-84.

29. McLean JW, Hubbard JR, Kedge MI. The science and art of dental ceramics. Volume 1: The nature of dental ceramics and their clinical use. Chicago: Quintessence Pub. Co. 1979.

30. Fehmi G, Ersan C, Caner O. Influence of repeated firings on the color parameters of two different all-ceramic materials.wiely library. 2018;43:606-11.

31. Sukumar R, Kumar KR, Reddy P, Krishna S, Navya RR. The effect of repeated firing on the color of ceramic system with two different veneering porcelain shades. J Adv Med Dent Scie Res. 2017; 5:78-81.

32. Öngül D, Rohlig BG, Gültekin P, Bultan Ö and Şerme B. Comparative Analysis of Color Parameters of Two Core Materials: Effect of Repeated Firings, Porcelain Thickness and Shade". EC Dental Science .2016; 626-34.

33. Chiche GJ and Pinault A: Esthetics of anterior fixed prosthodontics. Chicago: Quintessence.1994;97-113.

34. Tinschert J, Natt G, Mautsch W, Augthun M and Spiekermann H: Fracture resistance of lithium-disilicate, alumina and zirconia-based three-units fixed partial dentues: a laboratory study. Int Prosthodont. 2001;14: 231-8.

35. Piconi C, Maccauro G: Zirconia as a ceramic biomaterial. Biomater .1999; 20:1-25.

36. Derand T, Molin M, Kvam K: Bond strength of composite luting cement to zirconia ceramic surfaces. Dent Mater. 2005; 21: 1158- 62 .

37. Kaith O, Kusy RP, Whitely JQ: Zirconia brackets: an evaluation of morphology and coefficients of friction. Am J Orthod Dento-facial Orthop. 1994; 106: 605-14.

38. Guazzato M, Albakry M, Ringer SP, Swain MV. Strength, fracture toughness and microstructure of a selection of allceramic materials. Part II. Zirconia-based dental ceramics. Dent Mater. 2004;20:449-56. 
39. Douglas RD, Przybylska M: Predicting porcelain thickness required for dental shade matches. J Prosthet Dent.1999; 82:143-9.

40. Van der Burgt TP, ten Bosch JJ, Borsboom PC and Kortsmit WJ: A comparison of new and conventional methods for quantification of tooth color. J Prosthet Dent. 1990; 63:155-62.

41. Paravina RD, Powers JM. Esthetic Color Training in Dentistry. Mosby. 2004;90-129.

42. Schulze KA, Marshall SJ, Gansky SA, Marchal GW: Color stability and hardness in dental composites after accelerated aging. Dent Mater. 2003;19: 612-9.

43. Heffernan ML, Auilino SA, Diaz-Arnold AM, Haselton DR, Stanford CM and Vargas MA: Relative translucency of six all-ceramic systems. Part I: core materials. J Prosthet Dent .2002; 88: 4-9.

44. Ozturk O, Uludag B, Usumez A, Sahin V, Celik G: The effect of ceramic thickness and number of firings on the color of two all ceramic systems. J Prosthet Dent. 2008;100: 99-106.

45. Ghanbarzadeh J, Sabooni MR, Tehrani NA. The Influence of Repeated Firing on Color Stability of Two Porcelain Types. Journal of Medical Sciences. 2008; 8: 77-80.

46. Chen YM, Smales RJ, Yip KHK, Sung WJ: Translucency and biaxial flexural strength of four ceramic core materials. Dent Mater. 2008; 24: 1506-11.

47. Chaiyabutr Y, Kois JC, Lebeau D and Nunokawa G: Effect of abutment tooth color, cement color and ceramic thickness on the resulting optical color of a CAD/CAM Glass ceramic lithium disilicate reinforced crown. J Prosthet Dent .2011; 105:83-90.
48. Celik G, Uludag B, Usumez A, Sahin V, Ozturk O and Goktug G: The effect of repeated firings on the color of an all-ceramic system with two different veneering porcelain shades. J Prosthet Dent. 2008; 99: 203-8.

49. Sahin V, Uludag B, Usumez A, Ozkir SE: The effect of repeated firings on the color of an alumina ceramic system with two different veneering porcelain shades. J Prosthet Dent. 2010; 104: 372-8.

50. Crispin BJ, Seghi RR, Globe H: Effect of different metal ceramic alloys on the color of opaque and dentin porcelain J Prosthet Dent. 1991; 6:351-65.

51. Laund PS and Piotrowski TJ: Color changes of porcelain surface colorants resulting from firing. Int J Prosthodont. 1992; 5:22-7.

52. Pires de Souza Fde C, Casemiro LA, Garcia Lda F, Cruvinel DR. Color stability of dental ceramics submitted to artificial accelerated aging after repeated firings. 101: 13-8.

53. Qilo M, Gjerdet NR, Tvinnereim HM: The firing procedure influences the properties of zirconia core ceramic. Dent Mater. 2007; 24:471-5.

54. Al-Wahdani A and Martin DM: An in vitro the wear effects of glazed, unglazed and refinished dental porcelain on an opposing material. J Oral Rehabil. 1999; 26:538-46.

55. Anusavice KJ. Phillips science of dental materials. 11th ed. St. Louis: Elsevier.2003.p.672.

56. Aksoy G, Polat H, Polat M, Coskun G: Effect of various treatment and glazing techniques on the roughness and wettability of ceramic dental restorative surfaces. Colloid and Surface B: Biointerfaces .2006; 53:254-9.

57. Chueng KC, Darvell BW: Sintering of dental porcelain: effect of time and temperature on appearance and porosity. Dent Mater. 2002; 18:163-73. 